\title{
Reply to: Regarding lannicelli et al
}

\author{
Anna Maria lannicelli ${ }^{1 *}$, Daniele Vito ${ }^{1}$, Concetta Anna Dodaro ${ }^{2}$, Pasquale De Matteo ${ }^{3}$, Rita Nocerino ${ }^{1}$, \\ Angela Sepe ${ }^{1}$ and Valeria Raia ${ }^{1}$
}

\section{Reply}

Dear Dr. Chan and colleagues,

Thank you for your interest in our article, "Does Virtual Reality reduce pain in pediatric patients? A systematic review" (Ital J Pediatr. 2019 Dec 30;45 (1):171) [1].

While we absolutely agree with you on the need of clarification on a sentence in page 3 of the above mentioned manuscript, as you reasonably asked for, nevertheless we would like to expressly point out that an evident typing mistake has occurred which led to a frank misunderstanding. We accept responsibility related to this typo and apologize.

The correct sentence is "The sample size analyzed was numerically sufficient in the statistical analysis", and not "The sample size analyzed was not numerically sufficient in the statistical analysis".

You correctly highlighted that your group performed two studies ( $n=123$ and $n=131$ respectively), both of which exceeded the a priori power calculation required of 114 patients per clinical setting [2]. Again, we absolutely agree with you also on this point. Actually, in Table 1 of our article we specified that the sample sizes of your studies are by far the largest in the literature.

We do appreciate your comment, which gave us the opportunity of a clarification.

Sincerely yours,

Anna Maria Iannicelli on behalf of all co-authors.

\section{Authors' contributions}

The author(s) read and approved the final manuscript.

\footnotetext{
*Correspondence: annamaria.iannicelli@unina.it
}

${ }^{1}$ Department of Translational Medical Sciences, University of Naples "Federico II", Via Pansini 5, 80131 Naples, Italy

Full list of author information is available at the end of the article

\begin{abstract}
Author details
${ }^{1}$ Department of Translational Medical Sciences, University of Naples "Federico II", Via Pansini 5, 80131 Naples, Italy. ${ }^{2}$ Department of Advanced Biomedical Sciences, University of Naples Federico II, Naples, Italy. ${ }^{3}$ Department of Internal Medicine (Metabolic and Cardiac Rehabilitation Unit), University of Naples "Federico II", Naples, Italy.
\end{abstract}

Published online: 28 March 2021

\section{References}

1. Iannicelli AM, Vito D, Dodaro CA, De Matteo P, Nocerino R, Sepe A, et al. Does virtual reality reduce pain in pediatric patients? A systematic review. Ital J Pediatr. 2019;45(1):171. https://doi.org/10.1186/s13052-019-0757-0.

2. Chan E, Leong P. Regarding lannicelli et al. Ital J Pediatr. 2021. https://doi. org/10.1186/s13052-021-01009-4.

\section{Publisher's Note}

Springer Nature remains neutral with regard to jurisdictional claims in published maps and institutional affiliations.
Ready to submit your research? Choose BMC and benefit from:
- fast, convenient online submission
- thorough peer review by experienced researchers in your field
- rapid publication on acceptance
- support for research data, including large and complex data types
- gold Open Access which fosters wider collaboration and increased citations
- maximum visibility for your research: over 100M website views per year
At BMC, research is always in progress.
Learn more biomedcentral.com/submissions 